\title{
MEGI SUHERMAN SITUMEANG ANALISIS KELENGKAPAN STRUKTUR FISIK DAN BATIN PUISI OLEH SISWA KELAS X SMA SWASTA METHODIST 8 MEDAN T.P. 2019/2020
}

\section{ANALISIS KELENGKAPAN STRUKTUR FISIK DAN BATIN PUISI OLEH SISWA KELAS X SMA SWASTA METHODIST 8 MEDAN}

\author{
Megi Suherman Situmeang \\ Universitas Katolik Santo Thomas \\ megi.suherman@gmail.com
}

\begin{abstract}
Abstrak. Penelitian ini bertujuan untuk mendeskripsikan analisis kelengkapan struktur fisik dan batin puisi oleh siswa kelas X SMA Sw. Methodist 8 Medan. Puisi adalah sebuah struktur yang terbangun berdasarkan unsur fisik dan batin. Menganalisis unsur fisik dan batin puisi merupakan kegiatan menguraikan unsur-unsur yang terdapat di dalam puisi. Tujuan menganalisis unsur fisik dan batin adalah membedahkan hubungan antara unsur yang membangun struktur puisi. Adapun sampel yang digunakan sebanyak 30 siswa. Dari penelitianterlihat bahwa analisis kelengkapan struktur batin dan fisik oleh siswa kelas X SMA Swasta Methodist 8 Medan dapat dikatakan baik terbukti dari hasil peroleh rata-rata dari 30 siswa adalah 80 . Ditemukan ada 2 siswa yang memperoleh nilai 70 kategori Cukup, ada 7 siswa yang memperoleh nilai 75 , ada 11 siswa yang memperoleh nilai 80 kategori Baik, ada siswa 9 siswa yang memperoleh nilai 85 dan 1 siswa yang memperoleh 90 kategori Sangat Baik. Nilai rata-rata siswa dikatakan baik dengan nilai 80 . Dapat disimpulkan bahwa kelengkapan unsur batin dan fisik oleh siswa kelas X SMA Methodist 8 Medan sudah baik.

Kata Kunci: struktur fisik dan batin, puisi
\end{abstract}

\begin{abstract}
This study aims to describe the analysis of the completeness of the physical and mental structure of the poetry by class X SMA Sw. Methodist 8 Medan. Poetry is a structure that is built on the basis of physical and mental elements. Analyzing the physical and mental elements of poetry is an activity to describe the elements contained in poetry. The purpose of analyzing physical and mental elements is to dissect the relationships between the elements that make up the structure of the poetry. The sample used was 30 students. From the research, it can be seen that the analysis of the completeness of the mental and physical structures by class X SMA Private Methodist 8 Medan can be said to be good, as evidenced by the results obtained by an average of 30 students is 80 . get a score of 75 , There are 11 students who score 80 in the Good category, there are 9 students who get a score of 85 and 1 student who gets 90 in the Very Good category. The average score of students is said to be good with a value of 80 . It can be concluded that the completeness of the mental and physical elements by class $X$ SMA Methodist 8 Medan is good.

Keywords: physical and mental structure, poetry
\end{abstract}

\section{PENDAHULUAN}

\begin{abstract}
Peranan sastra dalam kehidupan manusia sebenarnya sangatlah besar. Menurut Rahmanto (2005:24), pengajaran sastra hendaknya mampu membina perasaan yang lebih tajam dibandingkan pelajaranpelajaran lainnya. Hal itu karena sastra memiliki kemungkinan yang lebih besar untuk mengantar manusia mengenal seluruh kemungkinan hidup seperti kebahagiaan, kebebasan, kesetiaan, kebanggaan, dan lainlain. Menurutnya, seseorang yang telah mendalami sastra biasanya memiliki
\end{abstract}

perasaan yang lebih peka untuk menunjuk hal yang bernilai dan yang tak bernilai. Pada intinya, manusia yang mendalami sastra dengan baik akan mampu menghadapi masalah-masalah hidupnya dengan pemahaman, wawasan, toleransi, dan rasa simpati yang lebih mendalam. Jadi, dari pendapat tersebut dapat disimpulkan bahwa peranan karya sastra bagi kehidupan manusia adalah dapat membentuk manusia yang mempelajari sebuah karya sastra menjadi peka terhadap banyak hal, dapat 
menemukan hal-hal yang bernilai dan tidak bernilai dalam kehidupan.

Puisi merupakan salah satu bagian dari karya sastra yang bersifat imajinatif yang mengandung nilai keindahan di dalamnya. Sastra menawarkan dua hal utama, yakni kesenangan dan pemahaman. Mengkaji sebuah karya sastra akan membantu kita untuk dapat memahami makna yang terkandung di dalam pengalaman-pengalaman pengarang yang disampaikan melalui para tokoh imajinatifnya. Pradopo (2007:7) bahwa puisi itu mengekspresikan pemikiran yang membangkitkan perasaan, yang merangsang imajinasi panca indra dalam susunan berirama. Selanjutnya puisi sebagai sistem penulisan yang margin kanan yang penggantian barisnya ditentukan secara internal dalam suatu mekanisme yang terdapat dalam baris itu sendiri.

Puisi adalah bentuk kesusastran yang mengungkapkan pikiran dan perasan penyair secara imajinatifdan disusun dengan mengkonsentrasikan bahasa, yakni, mengk onsentrasikan struktur fisik dan struktur batinya. Kosasih (203:235) mengemukakan puisi adalah karya sastra yang mengunakan kata-kata yang indah dan kaya makna. Selain itu, Djojosuroto (205:1) mengemukakan puisi merupakan gagasan yang dibentuk dengan susunan, penegasan, dan gambaran semua materi dan bagianbagianya yang menjadi komponenya dan merupakan suatu kesatuan yang indah.

Sepanjang zaman, puisi selalu mengalami perubahan dan perkembangan. Hal ini mengingat hakikatnya sebagai karya seni selalu terjadi ketegangan antara konvensi dan inovasi. Puisi selalu berubahubah sesuai dengan evolusi selera dan perubahan konsep estetiknya (Pradopo 2005:3). Maka dari itu, sangatlah sulit untuk membatasi pengertian puisi karena adanya perbedaan pendapat dan konsep dari setiap orang. Puisi merupakan ekspresi dari pengalaman imajinatif dari manusia, maka yang pertama kali diperoleh saat pembaca membaca puisi adalah pengalaman. Sehingga, semakin banyak membaca serta menikmati puisi, maka semakin banyak pula pengalaman yang diperoleh dan dinikmatinya.

Pengajaran puisi menjadi bagian tidak terpisahkan dari pengajaran sastra, sedangkan pengajaran sastra menjadi bagian dari pengajaran Bahasa dan Sastra Indonesia. Kenyataan ini menunjukkan bahwa pengajaran sastra termasuk di dalamnya pengajaran puisi, tidak berdiri sendiri, melainkan menjadi bagian tidak terpisahkan dari pengajaran bahasa dan sastra Indonesia.

Dunia pendidikan yang tidak lepas dari pengajaran sastra, khususnya dalam pengajaran apresiasi puisi di kalangan pelajar mulai dari tingkat Sekolah Dasar sampai Sekolah Menengah Atas belum mendapatkan hasil yang memadai. Karena puisi penting, maka puisi masuk dalam mata pelajaran Bahasa Indonesia di sekolah. Berbekal apresiasi sastra yang memadai, manusia dalam hal ini para siswa diharapkan mampu bersaing pada era global secara arif, matang, dan dewasa. Dalam konteks demikian, sastra menjadi semakin penting, bukan saja karena memiliki kontribusi besar dalam memperhalus budi, memperkaya batin dan dimensi hidup, melainkan juga telah masuk ke dalam kurikulum pendidikan. Melalui pergulatan dan pertemuan intensif dengan teks-teks sastra, para siswa akan mendapatkan bekal pengetahuan yang mendalam tentang manusia, hidup dan kehidupan, serta berbagai kompleksitas persoalan yang dihadapinya.

Pengajaran puisi di sekolah sering menekankan pada teori-teori puisi dan kurang membawa anak didik ke arah apresiasi puisi. Sering kali dalam mengajar guru hanya menyuruh siswa membaca puisi dan menjawab soal-soal yang ada kaitannya dengan puisi tersebut. Namun, ada permasalahan yang sebenarnya harus diselesaikan oleh guru dalam mengajarkan puisi yaitu mengenai pemahaman terhadap puisi, kelengkapan, dan kualitas puisi yang ditulis. Kelengkapan puisi yang menyangkut struktur fisik dan batin secara lengkap.

Berdasarkan pengamatan di lapangan banyak guru yang hanya memberikan tugas kepada siswa untuk membuat puisi berdasarkan ketentuan guru. Pembelajaran seperti itu pasti membuat siswa jenuh dan kebingungan untuk menemukan ide dan merangkai kata-kata menjadi sebuah puisi yang baik. Maka, peran seorang guru sangat penting untuk menentukan berhasil tidaknya pembelajaran menulis puisi pada siswa 


\section{HASIL PENELITIAN}

Analisis Puisi Penerimaan Karya Chairil Anwar

Penerimaan karya Chairil Anwar secara khusus menceritakan tentang seorang lelaki yang masih memberikan harapan kepada perempuan yang dulu pernah memiliki hubungan khusus. Hal ini kiranya sangat dikuatkan dengan penggambaran atau kalimat yang digunakan pada puisi oleh Ainun Jahriah

\section{Struktur Fisik}

Waluyo (1991:71) menyatakan bahwa unsur-unsur bentuk atau struktur fisik puisi yang diuraikan dalam bentuk metode puisi, yakni unsur estetik yang membangun struktur puisi. Unsur-unsur itu dapat ditelaah satu persatu, tetapi unsur-unsur itu merupakan kesatuan yang utuh. Unsur-unsur itu ialah diksi, pengimajian, kata konkret, bahasa figuratif (majas), rima, dan tata wajah puisi.

\section{a. Diksi (Pilihan Kata)}

Waluyo (1991:72) menjelaskan bahwa penyair sangat cermat dalam memilih katakata yang ditulis harus dipertimbangkan maknanya, komposisi bunyi dalam rima dan irama, kedudukan kata itu di tengah konteks kata lainnya, dan kedudukan kata dalam keseluruhan puisi itu. Oleh sebab itu, di samping memilih kata yang tepat, penyair juga mempertimbangkan urutan katanya dan kekuatan atau daya magis dari kata-kata tersebut. Dalam puisi "Penerimaan" terdapat beberapa pilihan kata yang digunakan oleh pengarang. Kata-kata yang digunakan pengarang mudah dipahami dan menggunakan makna sebenarnya seperti pada bait 1, yaitu

Kalau kau mau kuterima kau kembali

Dengan sepenuh hati

Aku masih tetap sendiri

\section{b. Pengimajian}

Pengimajian yang digunakan pengarang terdapat pada:

1. Indera penglihatan seperti pada bait 1 yaitu

Kalau kau mau kuterima kau kembali

Dengan sepenuh hati

Aku masih tetap sendiri

Dijelaskan bahwa kita bisa melihat bahwa ia masih sendiri dan belum ada yang menemani seperti kekasihnya menemani dahulu.

2. Indera perasaan terlihat pada kalimat Kutahu kau bukan yang dulu lagi
Bak kembang sari sudah terbagi

Bahwa pengarang merasakan adanya perubahan yang terjadi pada kekasihnya dahulu karena sikapnya sudah tidak sama seperti saat bersamanya.

\section{c. Kata Konret}

Kata konkret (nyata) atau the concrete word adalah kata yang kongkrit dan khusus, bukan kata yang abstrak dan bersifat umum (Tarigan, 2011: 32). Adapun kata konkret yang digunakan penyair contoh pada bait ke-1

\section{Kalau kau mau kuterima kau kembali \\ Dengan sepenuh hati \\ Aku masih tetap sendiri}

\section{d. Bahasa Figuratif (Majas)}

Majas yang digunakan adalah majas asosiasi (perumpamaan) yang membandingkan sesuatu dengan keadaan lainnya karena persamaan sifat. Terlihat pada kata "Bak".

\section{e. Rima}

Pada puisi "Penerimaan" rima terdapat pada semua bait yaitu pengulangan pada bunyi (i) pada kalimat terakhir.

Kemudian pengulangan kalimat pada bait 1 dan bait 4, yaitu pada kalimat

Kalau kau mau kuterima kau kembali danKalau kau mau kuterima kembali

\section{f. Tipografi}

Bentuk yang khas pada puisi "Penerimaan" ini menggunakan tipografi zigzag.

\section{Struktur Batin}

\section{a. Tema}

Berdasarkan uraian di atas kiranya makin menguatkan kita akan tema dalam puisi "Penerimaan" karya Chairil Anwar adalah percintaan

\section{b. Perasaan}

Puisi Lukai Aku Sekali Lagi karya Ainun Jahriah didalamnya menunjukkan kecewa dan pasrah itu sangat Nampak pada setiap baitnya. Yaitu tentang seorang lelaki yang masih memberi harapan pada perempuan yang dulu pernah memiliki hubungan khusus dengannya.

Kalau kau mau kuterima kau kembali

Dengan sepenuh hati

Aku masih tetap sendiri

Sang lelaki menyadari bahwa perempuan yang masih ia beri kesempatan kembali itu sudah tak sendiri. Maka ia ingin perempuan itu memutuskan keputusan secara tegas

Kutahu kau bukan yang dulu lagi 
Megi Suherman Situmeang

Analisis Kelengkapan Struktur Fisik dan Batin Puisi oleh Siswa Kelas X

SMA Swasta Methodist 8 Medan

Bak kembang sari sudah terbagi

Jangan tunduk! Tentang aku dan berani

Kalau kau mau kuterima kembali

Untukku sendiri tapi

Sedang dengan cerminanku enggan berbagi

\section{c. Nada dan Suasana}

Dalam hal ini, penyair merasakan sangat berharap dengan sedikit kecemasan bahwa sang mantan kekasih akan berpikir dan menimbang penawarannya dengan matang hingga ia akan kembali padanya.

Nada pada puisi penerimaan ini, penyair menuangkan perasaan harap-harap cemas dan ketegasan. Pengharapan yang ia rasakan dikarenakan pada dasarnya ia masih mencintai perempuan yang dimaksud. Logikanya adalah mana mungkin ia kembali memberikan kesempatan pada perempuan tersebut untuk kembali bila ia tidak mencintainya. Kemudian ketegasan adalah supaya perempuan tersebut memilih dengan tegas untuk kembali padanya atau terus bersama yang lain.

\section{d. Amanat}

Penyair berpesan agar perempuan itu mempertimbangkan penawaran penyair dan memutuskan dengan tegas keputusan yang akan ia ambil dan penyair mengabarkan kepada seluruh pembaca bahwa sosok penyair adalah sosok yang benci pada hal yang setengah-setengah. Penyair ingin mengabarkan pada setiap pembaca bahwa dirinya adalah sosok yang tegas dan menyukai ketegasan.

\section{Analisis Data}

Tabel 4.1

Hasil Analisis Kelengkapan Struktur Fisik Dan Batin Siswa

\begin{tabular}{ll}
\multicolumn{2}{l}{ Keterangan: } \\
$\mathrm{D}$ & : Diksi \\
$\mathrm{P}$ & : Pengimajian \\
$\mathrm{K}$ & : Kata Konret \\
$\mathrm{M}$ & : Majas \\
$\mathrm{R}$ & : Rima \\
$\mathrm{TP}$ & : Tipografi \\
$\mathrm{T}$ & : Tema \\
$\mathrm{A}$ & : Amanat \\
$\mathrm{P}$ & : Perasaan \\
$\mathrm{N}$ & : Nada/Suasana
\end{tabular}

\section{Temuan Penelitian}

Hasil perolehan nilai pada aspek diksi pada analisis kelengkapan struktur batin dan fisik terdapat 7 siswa yang memperoleh nilai 5 dan 23 siswa yang memperoleh nilai 10, pada aspek pengimajian terdapat 8 siswa yang memperoleh nilai 5 dan 22 siswa yang memperoleh nilai 10, pada aspek kata konkret ditemukan 16 siswa yang memperoleh nilai 5 dan 14 siswa yang memperoleh nilai 10, pada aspek majas ditemukan 13 siswa yang memperoleh nilai 5 dan 17 siswa yang memiliki 10, pada aspek rima ditemukan 17 siswa yang memiliki nilai 5 dan 13 siswa yang memiliki nilai 13, pada aspek tipografi ditemukan 21 siswa memperoleh nilai 5 dan 9 siswa yang memiliki nilai 10 , pada aspek tema ditemukan 3 siswa memperoleh nilai 5 dan sebanyak 27 siswa yang memperoleh nilai 10, pada aspek amanat ditemukan 2 siswa yang memperoleh nilai 5 dan sebanyak 28 siswa yang memperoleh nilai 10 , pada aspek perasaan ditemukan 17 siswa yang memperoleh nilai 5 dan 13 siswa yang memperoleh nilai 10, pada aspek

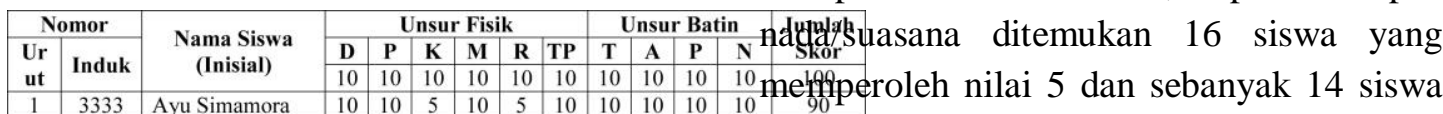

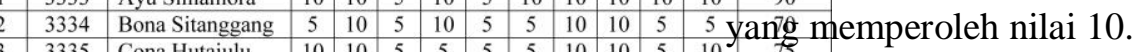
\begin{tabular}{ll|lllllllllllll}
4 & 3335 & Cona Hutajulu & 10 & 10 & 5 & 5 & 5 & 5 & 10 & 10 & 5 & 10 \\
\hline & 3336 & Dodi Panjaitan & 10 & 10 & 5 & 5 & 5 & 5 & 10 & 10 & 10 & 10 Tabel 4.2
\end{tabular}

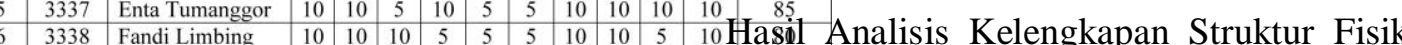

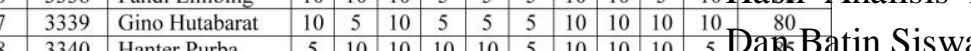

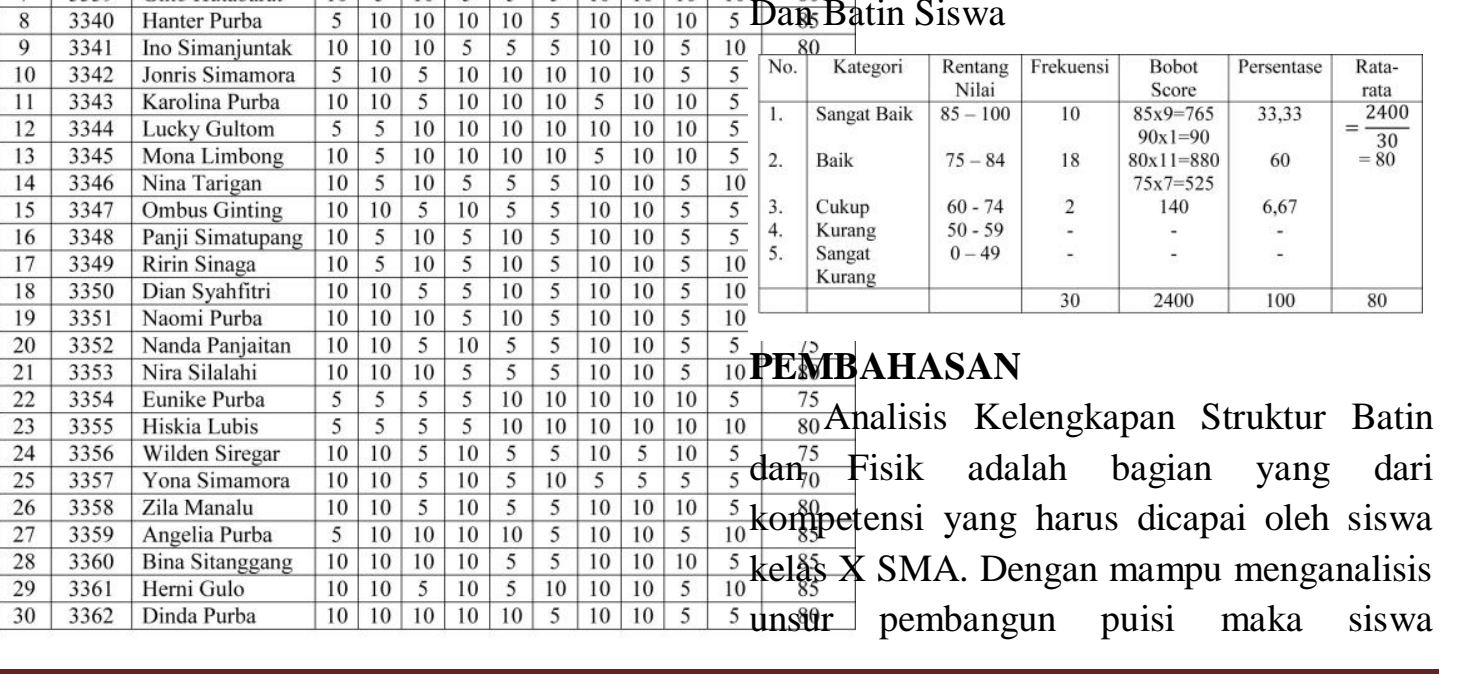

Jurnal Pendidikan Bahasa dan Sastra Indonesia 
diharapkan mampu menulis puisi dengan memperhatikan unsur pembangunnya (tema, diksi, gaya bahasa, imaji, struktur, perwajahan/tipografi).

Dari hasil penelitian di atas, terlihat bahwa analisis kelengkapan struktur batin dan fisik oleh siswa kelas X SMA Swasta Methodist 8 Medan dapat dikatakan baik terbukti dari hasil peroleh rata-rata dari 30 siswa adalah 80. Ditemukan ada 2 siswa yang memperoleh nilai 70 kategori Cukup, ada 7 siswa yang memperoleh nilai 75 , ada 11 siswa yang memperoleh nilai 80 kategori Baik, ada siswa 9 siswa yang memperoleh nilai 85 dan 1 siswa yang memperoleh 90 kategori Sangat Baik.

Menganalisis kelengkapan struktur batin dan fisik puisi adalah sebuah kompetensi dasar yang harus dimiliki oleh sisw kelas X SMA. Hal ini tercantum dalam Permendikbud 24 tahun 2016 yaitu butir 3.17 berisi menganalisis unsur pembangun puisi dan butir 4.17 menulis puisi dengan memerhatikan unsur pembangunnya (tema, diksi, gaya bahasa, imaji, struktur, perwajahan

Setelah melakukan analisis seperti yang di atas dengan melihat hasil siswa dalam menulis puisi dengan memperhatikan kelengkapan struktur batin dan fisik akhirnya dapat ditemukan hasil penelitian. Analisis kelengkapan struktur batin dan fisik pada siswa kelas X SMA Methodist 8 Medan merupakan sesuatu yang perlu ditingkatkan. Perlunya pembelajaran analisis struktur batin dan fisik ini lebih diarahkan pada praktik langsung atau menulis puisi dengan memerhatikan unsur pembangunnya baik itu fisik maupun batinnya.

Dari hasil pembelajaran analisis kelengkapan unsur intrinsik dan ekstrinsik puisi yang dilakukan diketahui bahwa nilai rata-rara siswa itu dikatakan baik dengan nilai 80. Maka dapat disimpulkan bahwa kelengkapan unsur batin dan fisik oleh siswa kelas X SMA Methodist 8 Medan sudah baik dan perlu ditingkatkan lebih baik lagi.

\section{SIMPULAN}

Berdasarkan hasil penelitian yang diuraikan pada bab IV maka dapat diambil kesimpulan sebagai berikut:

1. Nilai rata-rata kelengkapan struktur batin dan fisik siswa kelas X SMA
Swasta Methodist 8 Medan adalah 80 pada kategori Baik.

2. Hasil belajar analisis kelengkapan struktur batin dan fisik siswa kelas X SMA Swasta Methodist 8 Medan dengan jumlah siswa 30 orang dengan menulis puisi sesuai petunjuk yang diberikan guru dapat dikatakan baik sehingga kriteria ketuntasan minimal (KKM) terpenuhi bahkan lebih dari KKM.

\section{SARAN}

Berdasarkan hasil penelitian, maka peneliti menyarankan:

1. Kelengkapan struktur batin dan fisik puisi siswa perlu ditingkatkan lagi. Hal tersebut tentunya memerlukan model, media dan cara guru di dalam proses belajar mengajar di sekolah. Adanya model yang terpadu dan media pembelajaran yang mendukung materi struktur batin dan fisik puisi.

2. Model pembelajaran memerlukan pemahaman guru bahasa dan sastra Indonesia dari segi persiapan, pelaksanaan sampai evaluasi serta kerjasama guru dan siswa dalam proses pembelajaran sehingga tercapai apa yang diharapkan dari kompetensi dasar itu sendiri.

3. Disarankan agar peneliti selanjutnya tetap memperhatikan perkembangan model pembelajaran yang digunakan di sekolah dalam pembelajaran analisis struktur batin dan fisik puisi.

\section{DAFTAR PUSTAKA}

Aminuddin. 1987. Pengantar Apresiasi Apresiasi Karya Sastra. Bandung: Sinar Baru Algensindo.

Aminuddin (Ed). 1990. Sekitar Masalah Sastra: Beberapa Prinsi

Model Pengembangannya.

Yayasan Asih Asah Asuh.

Aminuddin. 2000. "Dekonstruksi dan Proses Pemaknaan Teks" Dalam Kajian Serba Linguistik untuk Anton Moelino Pereksa Bahasa. Bambang K. P. (Ed). Jakarta: Gunung Mulia

Arikunto, Suharsimi. dkk. 2007. Penelitian Tindakan Kelas. Jakarta: Bumi Aksara

Aritonang. K. 2006. Melatih Siswa Membuat Berbagai Ragam Tulisan. 
Megi Suherman Situmeang

Analisis Kelengkapan Struktur Fisik dan Batin Puisi oleh Siswa Kelas X

SMA Swasta Methodist 8 Medan

Jurnal Penelitian bidang pendidikan:

7(5) Desember: 72-85

Deporter. 2000. Quantum Learning Membiasakan Belajar Nyaman Dan Menyenangkan. Bandung: Penerbit Kaifa

Elliot, J. 1991. Action Research for Educational Change. Philadephia: Open University Press

Fishman, J.A. 1972. The Sosiology of Language. Rowly-Masschusett: Newbury House

Gani, R. 2000. "Pembenahan aspek interaksi proses belajar-mengajar bahasa dan sastra Indonesia". Makalah yang dipresentasikan pada Seminar Peringatan Bulan Bahasa yang Diselenggarakan oleh HMJ Bahasa dan Sastra Indonesia. FBS UNP. Padang, 11 November

Gerlach, V.G. Dan Ely, D.P. 1971. Teaching dan Melia. A Systematic Approach. Englewood Cliffs: Prentice-Hall, Inc

Laksana, A.S. 2007. Creative Writing: Tip dan Strategi Menulis Cerpen dan Novel. Jakarta: Pena

Latuheru, J. D. 1988. Media Pembelajaran Matematika dalam Proses Belajar Mengajar Masa Kini. Jakarta: Ditjen DIKTI Depdikbud

Nurgiantoro, Burhan. 1995. Teori Pengkajian Fiksi. Yogyakarta: Gadjah Mada University Press

Nurgiantoro, Burhan. 2005. Pembelajaran Berbasis Kompetensi dan Konstekstual bagi Guru, Kepala Sekolah dan Pengawas Sekolah. Jakarta: Rineka Cipta 